\title{
Application of theory of planned behavior to study online booking behavior
}

\author{
Yuli Christina ${ }^{a^{*}}$ and Ni Nyoman Kerti Yasa ${ }^{b}$
}

${ }^{a}$ Master of Management Program, Faculty of Economics and Business, Udayana University, Bali, Indonesia ${ }^{b}$ Faculty of Economics and Business, Udayana University, Bali, Indonesia

\section{H R O N I C L E}

\section{Article history:}

Received: March 01, 2021

Received in revised format: April

6, 2021

Accepted: May 31, 2021

Available online: May 31, 2021

Keywords:

Customer behavior

Post purchase behavior

Online booking

Theory of planned behavior

Online travel agencies

\section{A B S T R A C T}

Internet development has enormously influenced the world economy. Various offline buying and selling transactions, have now shifted into online transactions known as e-commerce. The online booking system was designed to ease customers on making rooms booking 24 hours a day. Online booking feature makes consumers able to access some key information, including hotel facilities, prices, reviews, which can be used as their deliberation on decision making and holiday planning. Traveloka as one of unicorn startup companies in Indonesia has contributes a significant impact on the acceleration of the online travel ecosystem growth rate, especially for the domestic market. There are many factors that must be examined in finding information, placing orders, and purchasing online. Therefore, this research is focused on analyzing online booking behavior. This study aims to determine the influence between variables based on Theory of Planned Behavior, which consists of attitude toward the online booking behavior, subjective norm, perceived behavioral control, online booking intention and online booking behavior at Traveloka. Data was collected from 133 respondents of domestic tourists who have made online bookings at Traveloka. Data were analyzed using Partial Least Square (PLS) statistics with the Smart PLS 3.0 M3 program to determine the complexity of the relationship between latent variables and their indicators. The results of this study indicate that attitude toward the behavior and subjective norms have a positive and significant effect on online booking intention. Meanwhile, perceived behavioral control has no significant effect on online booking intention. Another finding is that online booking intention and perceived behavioral control are known to have a positive and significant effect on online booking behavior. Traveloka management and marketers are also expected to be able to use the results of this research to evaluate and take corrective action on aspects that are deemed inadequate and manage the ease of use of the application to increase online booking intentions through the Traveloka application.

\section{Introduction}

The internet revolution in Information and Communication Technology (ICT) has had profound implications for the tourism industry. The internet allows tourists to access accurate, reliable information, shortens booking times and reduces costs in transactions with conventional methods. Based on the report "e-Conomy SEA 2018" released by Google and Temasek, it is known that the number of internet users in Indonesia, Malaysia, the Philippines, Singapore, Thailand and Vietnam has reached more than 350 million. This number is 90 million higher when compared to the number of internet users in 2015 . The report also reveals that the digital economy growth in Indonesia is the biggest and the fastest in 2018, the volume of transactions has exceeded 27 billion US dollars and will continue to grow to 100. billion US dollars in 2025 (Google and Temasek, 2018). This development creates "new" tourists, who are aware of the value of their money and time. The internet has become an effective means of conducting market research and offers a safe process for customers to place orders and pay for products in

* Corresponding author.

E-mail address: its.ychristina@gmail.com (Y. Christina) 
various time zones (Kotler and Keller, 2009: 324). Pabalkar (2014) mentions that one of the greatest benefits of online shopping is that this service is available 24 hours a day. $\mathrm{Gu} \& \mathrm{Wu}(2019)$ stated that online shopping has grown exponentially in the last five years. Chen et.al (2017) stated that in recent years, the internet has become the dominant distribution channel for hospitality products and services. Many hotels are aware of this trend and provide access to secure online reservation systems (Lien et.al, 2015). The hotel online booking system was created to make it easier for consumers to book rooms 24 hours a day. Apart from going through the hotel website, online booking services are also offered through Online Travel Agents (OTA's). With the availability of the online booking feature, consumers can access hotel information in detail and more transparently, besides that, consumers can also see reviews which can be used as their consideration in choosing hotels and planning holidays. Through this service, consumers can also search for room rates and room availability at the same time. The booking trend from traditional channels, has shifted to online booking. Prospective hotel guests or business guests both abroad and domestically assess Online Travel Agents as providing an online booking platform that is effective, efficient, and reliable. Online Travel Agents not only make the booking process easier, but also offer various services such as tour packages, car rental and tour guides (Turban, 2015). PhoCusWright's White Paper "Online Travel Agencies: More Than a Distribution Channel" report states that online travel agencies play a vital role in the distribution of the travel sector. The amount of gross bookings exceeded 150 billion US dollars in 2013, while in 2014 it represented 38\% of the global market. This is in line with the "e-Conomy SEA 2018" report released by Google and Temasek which reveals that online travel provides the largest and most stable contribution to the digital economy sector in Southeast Asia. The gross booking contribution reached US \$ 30 billion in 2018, experiencing a consistent increase of $15 \%$ annually in the 2015-2018 period. This achievement is influenced by increased consumer confidence in Online Travel Agents business agencies such as Agoda, Booking, Expedia and Traveloka, which offer a variety of flight options, hotels, lodging houses and other travel services. The "Year in Search: Insight for Brands" report released by Google, reveals that Indonesia is the largest and fastest growing online travel market in Southeast Asia. It has grown from US \$ 5 billion in 2015 to US \$ 10 billion in 2019 and is predicted to reach US \$ 25 billion in 2025. The significant development of Traveloka as an Indonesian online travel agent unicorn plays an important role in accelerating the growth rate of the online travel ecosystem, especially for the domestic market with an annual compound growth rate of 20\%. Traveloka's expansion in the Thai and Vietnamese markets has also contributed to the speed of growth in Southeast Asia. In the Siteminder report, which is one of the leading hotel channel management platforms, it is stated that Traveloka is the top 5 contributors to the top hotel booking revenue in 2019 in Indonesia. Research on the 2019 Indonesia Millennial Report, released by the IDN Research Institute, also states that the majority of millennials in Indonesia use the Traveloka application to make hotel bookings.

Popularities Online Travel Agents has received an important attention in recent years, but currently the literature and research related to online booking behavior is still limited. The limitations of literature that focus on discussing the development of online booking in Indonesia were also pointed out by Rosyidi (2018) in his research. Juniarti \& Priatnah (2018) state that there are quite a lot of Traveloka users in 2018, but it is not known how far the information system available at Traveloka can meet the needs of the Indonesian people. To respond to the empirical phenomenon of the development of Online Travel Agents in Indonesia, this research will focus on online booking behavior at Traveloka using the Theory of Planned Behavior (TPB) application model. Gelderen et al. (2008) revealed a more detailed and consistent theoretical specification of TPB, many studies have been tested using TPB in various fields. Several studies have used TPB as a basis for examining online purchasing behavior (Athiyaman, 2002; Gopi \& Ramayah, 2007; Laohapensang, 2009; Sentosa \& Mat, 2012; Mao \& Lyu, 2017; Lien et.al, 2015; Gu \& Wu, 2019). Rosyidi (2018) states that although the development of Online Travel Agencies (OTA) has received important attention in recent years, there is very little research that discusses the development of this service in Indonesia.

\section{Literature review}

\subsection{Theory of Planned Behavior (TPB)}

Theory of Planned Behavior (TPB) is a further development of The Theory of Reasoned Action (TRA) which was developed by Ajzen \& Fishbein in 1975. Ajzen (2005) stated that TPB begins by looking at the intention to behave as the closest antecedent of a behavior. It is believed that the stronger a person's intention to display a certain behavior, the more successful he is to do it. Intention is a function of beliefs and / or important information about the tendency that displaying a certain behavior will lead to a specific result. Based on this theory, a person's intention to behave is influenced by three factors, namely: attitude towards the behavior, subjective norms, perceived behavioral control. Attitude is the first antecedent of behavioral intentions. Attitude is a positive or negative belief to display a certain behavior. Gu \& Wu (2019) mention indicators to measure attitudes towards online purchase intentions, namely efficiency, saving time, being able to visit several sites at the same time, access to product information, product delivery, online shopping experience and the intention to go online again. George's (2004) research uses two sets of beliefs to measure attitudes towards buying via the internet, namely internet trustworthiness beliefs and unauthorized use beliefs. Subjective norms, the second determinant of intentions in TPB are assumed to be a function of beliefs that specifically a person agrees and disagrees with presenting a behavior. The individuals and groups above are called referents. Laohapensang (2009) states that the subjective norm is a belief about normative expectations from family, friends, and superiors. The significant effect of subjective norms on intention to behave was found in the research of Gu \& Wu (2019). Likewise, Mao \& Lyu (2017) found that subjective norms have a positive and significant effect on intention to book Airbnb. 
Ajzen (2005) defines perceived behavioral control (PBC) as a feeling of self-efficacy or a person's ability to show desired behavior. PBC is determined by two components. The first is control belief, which is an individual's belief about the presence of control which functions as a support or barrier to an individual's behavior. The second component is perceived power, which is the individual's perception of how strong the control is to influence himself in behavior.

\subsection{Intention}

The harder a person's intention to engage in a behavior, the greater the tendency for him to perform the behavior (Ajzen, 1991). Gupta \& Duggal (2020) in their research also stated that the intentions of users of online food delivery applications such as the intention to reuse and WOM are defined as "part of behavior". George (2002), Ajzen (2005), Sentosa \& Nik Mat (2012) found that intention has a positive and significant influence on internet purchasing behavior.

\subsection{Behavior}

Kotler \& Keller (2009) in their book states that consumer purchasing behavior is influenced by cultural, social, and personal factors. The harder a person tries or how much effort is made to display a behavior, the greater the tendency for him to do the behavior (Ajzen, 1991).

\section{Hypotheses and Research Conceptual Frameworks}

The conceptual framework of this research is shown in the following figure:

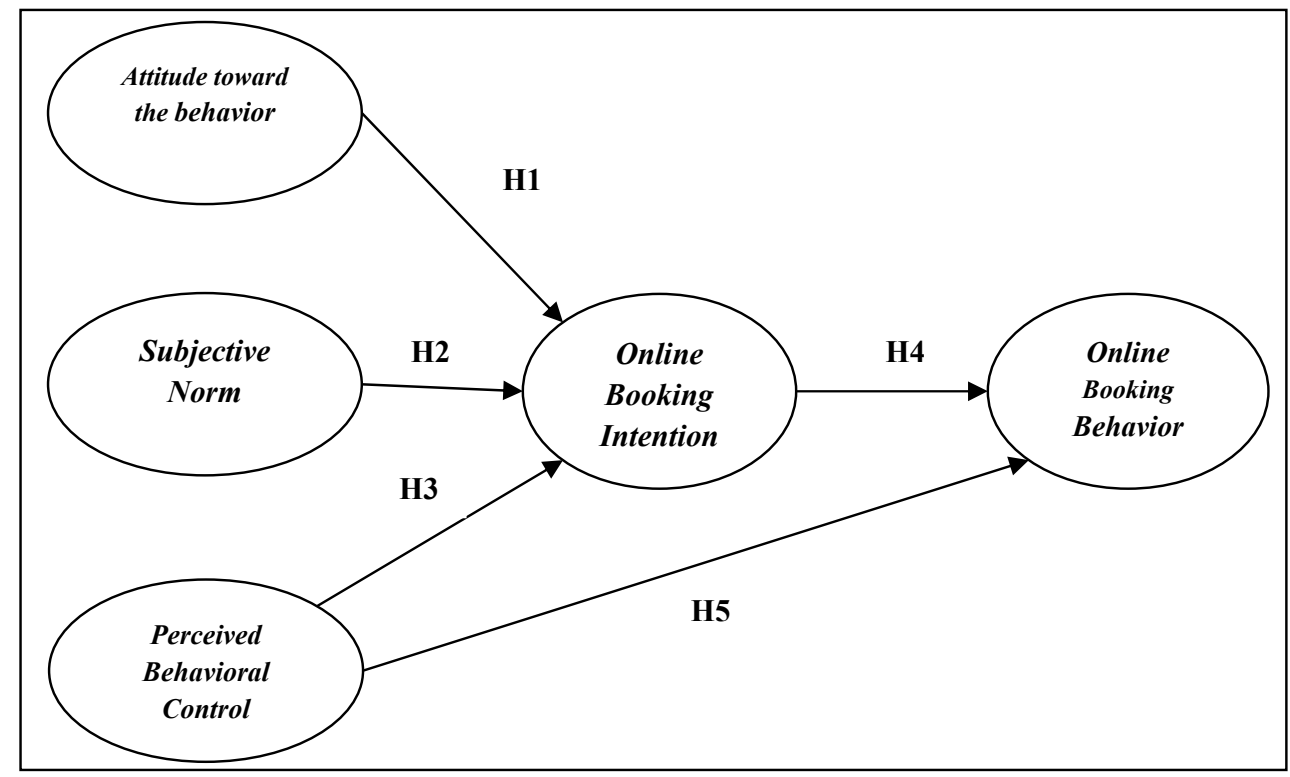

Fig. 1. Research Concept Framework

Based on the theoretical concepts and empirical findings that have been presented, the research hypothesis is formulated as follows:

\subsection{The influence of attitude toward the online booking behavior on the intention to make online bookings}

Attitude by Ajzen (2005) is defined as a disposition or tendency to respond to things that are evaluative, liked, or disliked towards objects of people, institutions, or events. Attitudes towards behavior are determined by evaluation of the consequences of behavior and how strongly these consequences are associated with behavior. Research conducted by Dharmesti et al. (2019) found that there was a positive relationship between attitude towards online shopping and online purchase intentions for Australian and American millennials. Research results from Mao \& Lyu (2017), Gu \& Wu (2019) also found that attitude toward online shopping behavior has a significant effect on online shopping behavior intention. On the other hand, Laohapensang (2009) stated that attitude towards internet shopping statistically does not have a significant effect on online shopping intention. Based on these empirical studies, the first hypothesis can be formulated:

$\mathrm{H}_{1}$ : Attitude toward the online booking behavior has a positive and significant effect on intention to make online bookings. 
Laohapensang (2009) states that the subjective norm is a belief about normative expectations from family, friends and superiors. The significant effect of subjective norms on intention to behave was found in the research of Gu \& Wu (2019). Likewise, Mao \& Lyu (2017) found that subjective norms have a positive and significant effect on intention to book Airbnb. However, the opposite results found in the research of Armitage \& Conner (2001), it was found that subjective norms are the worst predictors that affect intention when compared to attitude and perceived behavioral control. Then the second hypothesis tested is:

\section{$\mathrm{H}_{2}$ : Subjective norms have a positive and significant effect on the intention to make online bookings.}

\subsection{The effect of perceived behavioral control on the intention to make online bookings}

The results of the meta-analytic review conducted by Armitage and Corner (2001) found that the effect of perceived behavioral control on intention to behave was greater than the influence of subjective attitudes and norms. Laohapensang (2009) in his research also found that perceived behavioral control is the most important factor influencing internet purchasing behavior in Thailand. Research by $\mathrm{Gu}$ and $\mathrm{Wu}$ (2019) found that when compared to attitude and subjective norms, perceived behavioral control has the most significant effect on online purchase intention. However, a contradictory result is found in Mao and Lyu's (2017) study which states that perceived behavioral control does not have a significant effect on repurchasing intentions on the Airbnb site. The third hypothesis is formulated as follows:

\section{$\mathrm{H}_{3}$ : Perceived behavioral control has a positive and significant effect on the intention to make online bookings.}

\subsection{Effect of intention to make online booking on online booking behavior}

The harder a person's intention to engage in a behavior, the greater the tendency for him to actually perform the behavior (Ajzen, 1991). Gupta and Duggal (2020) in their research also stated that the intentions of users of online food delivery applications such as the intention to reuse and WOM are defined as "part of behavior". Ajzen (2005), Sentosa \& Nik Mat (2012), Bhatti (2018) in their research found that intention has a positive and significant effect on internet purchasing behavior. The hypothesis being tested is:

\section{$\mathrm{H}_{4}$ : Online booking intention has a positive and significant effect on online hotel behavior}

\subsection{The effect of perceived behavioral control on online booking behavior}

Ajzen (1991) suggests that perceived behavioral control can have a direct effect in shaping behavior. A significant relationship between perceived behavioral control and the behavior of using information technology was found in the test competing models research conducted by Taylor and Todd (1995). Gopi and Ramayah (2007) examined the application of theory of the planned behavior in predicting the intention to trade online, it was found that perceived behavioral control had a significant effect on actual usage. Based on this research, the fifth hypothesis can be formulated:

$\mathrm{H}_{5}$ : Perceived behavioral control has a positive and significant effect on online hotel booking behavior.

\section{Research Methods}

This research was conducted at Traveloka and data collection was carried out in January 2021 by taking individual consumer subjects. The predictor variables $(\mathrm{X})$ in this study were attitude toward the online booking behavior, subjective norm and perceived behavioral control. The response variable is the variable that becomes the result or output because of the input variable. The response variable (Y) in this study is online booking intention and online hotel booking behavior. The population in this study were consumers of online travel sites and applications, Traveloka. The sample determination in this study is nonpurposive sampling, so that there are questions that function as filters at the beginning of the questionnaire. The characteristics that are included as sample members are consumers who have made online bookings on the Traveloka website or application. The questionnaire consists of five parts: first, a statement to identify attitude, measured by six indicators; second, a statement to identify subjective norms, measured by three indicators; third, a statement to identify perceived behavioral control, measured by four indicators; fourth, a statement to identify intentions, measured by three indicators; fifth, a statement to identify booking behavior, measured by three indicators. Statement items are measured using a Likert scale, where 1 strongly disagrees and 5 strongly agrees. The validity and reliability of the research instruments were tested. Data analysis in this study used the Partial Least Square (PLS) approach. PLS is used to determine the complexity of the relationship between latent variables and their indicators. 


\section{Data Analysis}

\subsection{Responsive Characteristics}

The majority of respondents aged 17 to 27 years with a percentage of 51.9 percent, then followed by respondents with an age range of 27 to 37 years at 41.4 percent, and respondents with an age range of 47 to 47 years at 6.8 percent. In terms of gender, female respondents dominated, namely 69.2 percent, while male respondents were 30.8 percent. Based on their education data, the majority of respondents were respondents with the latest education level of Diploma or S1 with a percentage of 88.7 percent. This was followed by recipients with the last S2 education level, which was 6.8 percent and those with the last high school education level having the smallest number, namely 4.5 percent. In terms of online booking destinations at Traveloka, the majority of respondents aim for a vacation with a percentage of 90.2 percent, while business and other destinations have the same percentage of 3.8 percent and school destinations with the smallest number of 2.3 percent. Based on the area of origin of the respondents, the majority came from Bali with a total percentage of 41.4 percent. Then followed by Surabaya at 24.1 percent, Jakarta at 19.5 percent, Bandung 3 percent and other regions at 12 percent.

\subsection{Descriptive analysis of variables}

Descriptive analysis was carried out to determine the characteristics and responses of respondents to each statement. All variables are described using mean values. The scale category for each variable is determined by the range of criteria as follows

$$
1.00-1.79=\text { very low; } 1.80-2.59=\text { low; } 2.60-3.39=\text { quite high; } 3.40-4.19=\text { height; } 4.20-5.00=\text { very high }
$$

\section{Table 1}

Results of Descriptive Statistical Analysis

\begin{tabular}{ll}
\hline Variable & Average value \\
\hline Attitude toward the online booking behavior $(\mathrm{X} 1)$ & 4.28 \\
Subjective Norms $(\mathrm{X} 2)$ & 3.82 \\
Perceived Behavioral Control (X3) & 4.43 \\
Online Booking Intention (Y1) & 4.18 \\
Online booking behavior (Y2) & 3.77 \\
\hline
\end{tabular}

Based on Table 1, it can be seen that all statement items on the purchase intention variable have a Pearson product moment correlation coefficient value of more than 0.3 , so the statement items in the research instrument are valid and fit for use as a research instrument.

\subsection{Data analysis}

In quantitative research, data analysis activities are divided into two, namely the activity of describing the data and conducting statistical tests (inference). This research uses Smartpls 3.0 software.

\subsubsection{Evaluate the outer model for reflective indicators}

\subsubsection{Convergent validity test}

Convergent validity can be seen from the average variance extracted (AVE) value for each variable.

\section{Table 2}

convergent validity test result

\begin{tabular}{lc}
\multicolumn{1}{c}{ Variable } & AVE \\
\hline Attitude toward the online booking behavior $(\mathrm{X} 1)$ & 0.576 \\
Subjective Norms $(\mathrm{X} 2)$ & 0.668 \\
Perceived Behavioral Control (X3) & 0.725 \\
Intention (Y1) & 0.783 \\
Online booking behavior (Y2) & 0.747 \\
\hline
\end{tabular}

In this study, the AVE value of all variables listed in Table 2 is above 0.5 , which means that the convergent validity requirements of all variables are met. The results of this test indicate that all indicators are valid and feasible indicators to measure their respective variables.

\subsubsection{Convergent validity test}

Table 3 present the results of the convergent reliability. 
Table 3

Discriminant Validity

\begin{tabular}{lcccc}
\hline & $\begin{array}{c}\text { Attitude } \\
\text { Toward the } \\
\text { Behaviour }\end{array}$ & $\begin{array}{c}\text { Online Booking } \\
\text { Behavior }\end{array}$ & $\begin{array}{c}\text { Online Booking } \\
\text { Intention }\end{array}$ & $\begin{array}{c}\text { Perceived Behavioral } \\
\text { Control }\end{array}$ \\
\hline Attitude Toward the Behaviour & 0,759 & & & \\
Online Booking Behavior & 0,696 & 0,864 & 0,885 & \\
Online Booking Intention & 0,739 & 0,681 & 0,618 & 0,852 \\
Perceived Behavioral Control & 0,692 & 0,625 & 0,627 & 0,553 \\
Subjective Norm & 0,639 & 0,579 & 0,817 \\
\hline
\end{tabular}

The results of discriminant validity in table 3 state all cross loading values for each indicator on each variable $>$ than 0.5 . Thus it can be stated that the data in the study are valid.

\subsubsection{Composite Reliability}

Table 4

Coef. Composite Reliability dan Cronbach's Alpha Cronbach's Alpha

\begin{tabular}{lcc}
\hline Variable & Composite Reliability & Cronbach's Alpha \\
\hline Attitude Toward the Behavior & 0,890 & 0,852 \\
Subjective Norm & 0,856 & 0,747 \\
Perceived Behavioral Control & 0,913 & 0,874 \\
Online Booking Behavior & 0,898 & 0,829 \\
Online Booking Intention & 0,915 & 0,861 \\
\hline
\end{tabular}

Composite reliability is a group of indicators that measure a variable having a good composite reliability. Composite Reliability measures the internal consistency, and the value must be above 0.60 and the Cronbach alpha value is greater than 0.70 based on the Chin method. Table 3 shows that the value of the composite reliability coefficient above is above the criteria, namely $>0.70$ so that this study has good reliability in each of its variables.

\subsubsection{Inner model evaluation}

\subsubsection{R-square $\left(R^{2}\right)$}

Based on Table 5 and Fig. 2, it can be seen that the R-square $\left(\mathrm{R}^{2}\right)$ value of the online booking intention (Y1) variable is 0.599. This value can explain that $59.9 \%$ of changes in online booking intention (Y1) are strongly influenced by exogenous variables in this study, while $40.1 \%$ of changes in the online booking intention (Y1) variable are influenced by variables outside the model. Furthermore, the value of the R-square $\left(\mathrm{R}^{2}\right)$ value of the online booking behavior (Y2) variable is 0.531 . This value can explain that $53.1 \%$ of changes in the online booking behavior variable (Y2) are strongly influenced by exogenous variables in this study, while $46.8 \%$ of changes in the online booking behavior variable (Y2) are influenced by variables outside the model. So that overall, the R-square $\left(\mathrm{R}^{2}\right)$ value of all variables is more than 0.50 so that it is included in the strong criteria and it can be said that the model formed is considered strong enough.

Table 5

$\underline{\text { R-square }\left(\mathbf{R}^{2}\right) \text { Value Variable Endogen }}$

\begin{tabular}{ccc} 
R-square $\left(\mathbf{R}^{2}\right)$ Value Variable Endogen & R-Square & R-Square Adjusted \\
\hline Variable & 0,599 & 0,590 \\
Online Booking Intention (Y1) & 0,531 & 0,523 \\
\hline Online Booking Behavior (Y2) & & \\
\hline
\end{tabular}

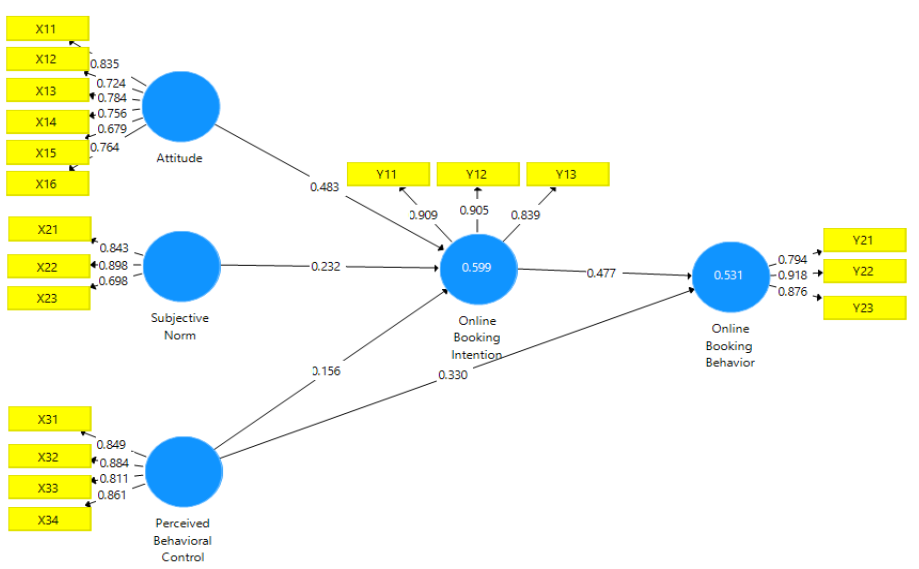

Fig. 2. Algorithm Diagram of SEM-PLS Analysis Results 


\subsubsection{Q-square (predictive relevance)}

Q-square (predictive relevance) aims to measure how well the observed value generated by the estimation model and its parameters. Q-square value> 0 indicates that the model has good predictive relevance. The Q-square (predictive relevance) value can be calculated as follows:

$\mathrm{Q}^{2}=1-(1-\mathrm{R} 21)(1-\mathrm{R} 22)=1-(1-0,599)(1-0,531)=1-(0,401)(0,469)=1-(0,1881) 0,8119$ or $81,2 \%$

Through the calculation of the Q-square (predictive relevance) the value is above 0 and close to 1 , namely 0.8119 or $81.2 \%$, which means that the model has a good value. This value shows that $81.2 \%$ of changes or variations in the variable online booking intention (Y1) and online booking behavior (Y2) have a predictive value or the model deserves to be said to have a relevant predictive value.

\subsection{Hypotheses Test}

The significance of the estimated parameters provides very useful information about the relationship between the research variables. The basis used in testing the hypothesis is the value contained in the output path coefficient and the total effects which are presented in Table 6 below:

Table 6

Direct effect test result

\begin{tabular}{|c|c|c|c|c|c|}
\hline & $\begin{array}{c}\text { Original } \\
\text { Sample }(O)\end{array}$ & $\begin{array}{c}\text { Sample } \\
\text { Mean }(M)\end{array}$ & $\begin{array}{l}\text { Standard Devi- } \\
\text { ation (STDEV) }\end{array}$ & $\begin{array}{c}\text { T Statistics } \\
(\mid \mathrm{O} / \mathrm{STDEV})\end{array}$ & $P$ Values \\
\hline Attitude Toward the Behavior $\rightarrow$ Online Booking Intention & 0.483 & 0.489 & 0.110 & 4.378 & 0.000 \\
\hline Subjective Norm $\rightarrow$ Online Booking Intention & 0.232 & 0.228 & 0.086 & 2.704 & 0.007 \\
\hline Perceived Behavioral Control $\rightarrow$ Online Booking Intention & 0.156 & 0.158 & 0102 & 1.525 & 0.128 \\
\hline Online Booking Intention $\rightarrow$ Online Booking Behavior & 0.477 & 0.473 & 0.086 & 5.564 & 0.000 \\
\hline Perceived Behavioral Control $\rightarrow$ Online Booking Behavior & 0.330 & 0.338 & 0077 & 4.271 & 0.000 \\
\hline
\end{tabular}

Hypothesis testing is done using t-statistics and seeing the p-value. If the t-statistics value $\geq \mathrm{t}$-table value (1.96) or p-value $<0.05$, then Ho is rejected and the research hypothesis is accepted for each variable which is explained as follows,

1. Attitude toward the behavior towards online booking intention has a $t$ statistics value of 4.378 , and a $P$ value of 0.000 , because $\mathrm{P}$ values $<0.05(0.000<0.05)$ then the hypothesis is accepted. This shows that there is a positive influence between attitude toward the behavior towards online booking intention which can be seen in the path coefficient of 0.483 which is positive, because the path coefficient value is positive, which means that attitude toward the behavior is positive towards online booking intention. This means that the more positive the attitude toward the behavior, the more online booking intention will be increased.

2. Subjective norm towards online booking intention has a t statistics value of 2.704 , and a $P$ value of 0.007 , because $P$ values $<0.05(0.007<0.05)$ then the hypothesis is accepted. This shows that there is an influence between subjective norms on online booking intention. Judging from the path coefficient of 0.232 is positive, because the path coefficient is positive, which means that the subjective norm has a positive effect on online booking intention. This means that the more positive subjective norms, the more online booking intention will be increased.

3. Perceived Behavioral Control on online booking intention has a statistical t value of 1.525 , and a $\mathrm{P}$ value of 0.128 , because $\mathrm{P}$ values $>0.05(0.128>0.05)$, the hypothesis cannot be accepted (rejected). This shows that there is no significant influence between perceived behavioral control on online booking intention. Even though the path coefficient value is positive at 0.156 , the better perceived behavioral control has not been able to increase online booking intention.

4. Online booking intention for online booking behavior has a t statistics value of 5.564, and a $\mathrm{P}$ value of 0.000 , because $\mathrm{P}$ values $<0.05(0.000<0.05)$, the hypothesis is accepted. This shows that there is a positive influence between online booking intention on online booking behavior which can be seen in the path coefficient of 0.477 which is positive, because the path coefficient value is positive, meaning that online booking intention has a positive effect on online booking behavior. This means that the higher online booking intention, the more online booking behavior will be increased.

5. Perceived Behavioral Control on online booking behavior has a statistical $t$ value of 4.271 , and a $P$ value of 0.000 , because $\mathrm{P}$ values $<0.05(0.000<0.05)$ then the hypothesis is accepted. This shows that there is an influence between perceived behavioral control on online booking behavior. Judging from the path coefficient of 0.330 is positive, because the value of the path coefficient is positive, it means that perceived behavioral control has a positive effect on online booking behavior. This means that the higher the perceived behavioral control, the more online booking behavior will be increased. 


\section{Discussion}

The path coefficient of attitude toward the behavior towards online booking intention is 0.483 and the t-statistics value is 4.378 , indicating that attitude toward the behavior has a positive effect on online booking intention. The more positive the attitude toward the behavior, the more online booking intention will be increased. This explanation is in line with the results of research from Dharmesti, et al. (2019) which found that there is a positive relationship between attitude towards online shopping and online purchase intentions for Australian and American millennials. Likewise, research from Gu \& Wu (2019) states that attitude toward behavior has a significant effect on online purchase intention. The path coefficient of subjective norm on online booking intention is 0.232 and the $t$-statistics value is 2.704 , indicating that subjective norm has a positive effect on online booking intention. This proves that the more positive subjective norms are, the more online booking intention increases. This finding is in line with the results of research by Mao \& Lyu (2017) which found that subjective norms have a positive and significant effect on intention to book Airbnb. Likewise, research by Gu \& Wu (2019) which states that subjective norms have a significant effect on online purchase intention. The path coefficient of the perceived behavioral control on online booking intention is 0.156 and the t-statistics value is 1.525 . The path coefficient shows that the perceived behavioral control does not have a positive effect on online booking intention. This proves that the better the perceived behavioral control is not yet able to increase booking intention. This finding is in line with the results of research from Mao \& Lyu (2017) which found that perceived behavioral control did not have a significant effect on the intention to make repurchases on the Airbnb site. The low significance of perceived behavioral control on booking intention in this study may be because online booking at Traveloka is fully under consumer control. The result of online booking intention's path coefficient on online booking behavior is 0.477 and the t-statistics value is 5.564, this shows that online booking intention has a positive influence on online booking behavior. The higher online booking intention, the more online booking behavior will be increased. This explanation is in line with Tenkasi \& Zhang (2018) who found that intention has a positive and significant effect on actual behavior. Likewise, research from Ajzen (2005), Sentosa \& Nik Mat (2012), Bhatti (2018) found that intention has a positive and significant effect on internet purchasing behavior. The path coefficient of perceived behavioral control on online booking behavior is 0.330 and the t-statistics value is 4.271 . This shows that perceived behavioral control has a positive effect on online booking behavior. The better the perceived behavioral control, the more online booking behavior increases. This explanation is in line with the results of research by Gopi \& Ramayah (2007) which examined the application of theory of planned behavior in predicting intentions to trade online, it was found that perceived behavioral control had a significant effect on actual usage.

\section{Conclusions, Implications, Limitations of the Research}

Based on the results of data analysis and the discussion, it can be concluded that attitude toward the behavior and subjective norms have a positive and significant effect on online booking intention. Meanwhile, perceived behavioral control has no significant effect on online booking intention, where better perceived behavioral control has not been able to increase online booking intention at Traveloka. Another finding is that online booking intention and perceived behavioral control are known to have a positive and significant effect on online booking behavior. The results of this study have several implications for Traveloka management, including pricing and marketing strategy as well as system evaluation and company reputation maintenance. In regards to pricing strategy, management is expected to ensure the best price is offered to consumers. Management needs to analyze the market update, make a price adjustment by periodically evaluate the system. Concerning to the marketing strategy, additional promotions including discount, free coupons or vouchers can be implemented. Further, gamification on the marketing strategy such as lottery can also be done. In addition, family package offer can be considered in order to stimulate families making online bookings on the Traveloka application. Addressing to system evaluation, management needs to evaluate the applications to ensure it is user friendly, has an ease payment feature, as well as periodic update on the most recent situation demand, for example providing contactless check-in services and cleanliness assurance programs on current pandemic conditions. Last thing to consider that management must also maintain the company reputation, especially in the travel community, one of which is by managing negative online comments written by consumers. It is to show that the company cares about the dissatisfaction experienced by consumers.

\section{References}

Ajzen, I. (1991). The theory of planned behavior. Organizational behavior and human decision processes, 50(2), $179-211$. Ajzen, I. (2005). Attitudes, Personality and Behaviour. $2^{\text {nd }}$ ed., McGraw-Hill International.

Armitage, C. J., \& Conner, M. (2001). Efficacy of the theory of planned behaviour: A meta-analytic review. British Journal of Social Psychology, 40(4), 471-499.

Athiyaman, A. (2002). Internet users' intention to purchase air travel online: an empirical investigation. Marketing Intelligence \& Planning, 20(4), $234-242$.

Bhatti, A. (2018). Consumer Purchase Intention Effect on Online Shopping Behavior with the Moderating Role of Attitude. International Journal of Academic Management Science Research (IJAMSR), 2, 44-50.

Chen, C., Xie, K., \& Wang, S. (2017). The influence of incidental affect and mood-changing price on online booking intention. Journal of Hospitality and Tourism Technology, 8(3). 
Dharmesti, M., Dharmesti, T. R. S., Kuhne, S., \& Thaichon, P. (2019). Understanding online shopping behaviours and purchase intentions amongst millennials. Young Consumers.

Van Gelderen, M., Brand, M., Van Praag, M., Bodewes, W., Poutsma, E., \& Van Gils, A. (2008). Explaining entrepreneurial intentions by means of the theory of planned behaviour. Career development international, 13(6), 538-559.

George, J. F. (2002). Influences on the intent to make Internet purchases. Internet Research, 12(2), 165-180.

George, J. F. (2004). The theory of planned behavior and Internet purchasing. Internet Research, 14(3), 198-212.

Google Temasek. (2018). e-Conomy SEA 2018: Southeast Asia's Internet Economy Hits an Inflection Point.

Gopi, M., \& Ramayah, T. (2007). Applicability of theory of planned behavior in predicting intention to trade online: Some evidence from a developing country. International Journal of Emerging Markets, 2(4), 348 - 360.

Gu, S., \& Wu, Y. (2019). Using the Theory of Planned Behaviour to Explain Customers' Online Purchase Intention. World Scientific Research Journal, 5(9), 226-249.

Gupta, V., \& Duggal, S. (2020). How the consumer's attitude and behavioural intentions are influenced: A case of online food delivery applications in India. International Journal of Culture, Tourism and Hospitality Research, 15(1).

Januarti, E. K., \& Priantinah, D. (2018). Reviewing the development of information, service, and website quality towards Traveloka customer satisfaction in Indonesia. Petra International Journal of Business Studies, 1(2), 63-69.

Kotler, P., \& Keller, K.L. (2009). Manajemen Pemasaran. Penerbit Erlangga.

Laohapensang, O. (2009). Factors influencing internet shopping behaviour: a survey of consumers in Thailand. Journal of Fashion Marketing and Management: An International Journal, 13(4), 501 - 513.

Lien, C. H., Wen, M. J., Huang, L. C., \& Wu, K. L. (2015). Online hotel booking: The effects of brand image, price, trust and value on purchase intentions. Asia Pacific Management Review, 20(4), 210-218.

Mao, Z., \& Lyu, J. (2017). Why travelers use Airbnb again?. International Journal of Contemporary Hospitality Management, 29(9).

Pabalkar, V. (2014). Drivers of shopping Begaviour. Procesia Ecomonics and Finance 11, 600-608.

Pradika, G.A., Rahyuda, K., Kerti, Y. N. N., \& Giantari, I.G.A.K. (2018). The Influence of Social Value on the Attitude of M-Advertising Users and the Purchase Intention of the Millenial Generation on the Instagram Application. European Journal of Business and Management, 10(12).

PhoCusWright. (2013). Asia Pacific Online Travel Overview Sixth Edition: Special Report for ITB Asia.

PhoCusWright's White Paper. (2014). Online Travel Agencies: More Than a Distribution Channel.

Rosyidi, M. I. (2018). Indonesian Online Travel Agencies: Profiling the Services, Employment, and Users. Advances in Social Science, Education and Humanities Research, 259.

Sentosa, I., \& Mat, N.M.N. (2012). Examining a Theory of Planned Behavior (TPB) and Technology Acceptance Model (TAM) in Internet Purchasing Using Structural Equation. Journal of Arts, Science \& Commerce, 3, 62-77.

Taylor, S.., \& Todd, P.A. (1995). Understanding Information Technology Usage: A test Competing Models. Information System Research, 6(2), 144-176.

Tenkasi, R. V., \& Zhang, L. (2018). A Test of the Theory of Planned Behavior: Influencing Behavioral Change to go Green”, Research in Organizational Change and Development, 127-165.

Turban, E. T., \& King Jae Kyu Lee, D. K. J. K. (2015). Electronic Commerce A Managerial and Social Networks Perspective. Traveloka. (2021). About Traveloka. (www.traveloka.com/en-id/about- us).

\begin{tabular}{|c|c|}
\hline Variable & Research Question \\
\hline \multirow{6}{*}{$\begin{array}{l}\text { Attitude toward the online booking be- } \\
\text { havior }\end{array}$} & I feel happy making online bookings at Traveloka \\
\hline & I got clear product information when making online bookings on Traveloka \\
\hline & I feel safe when making online bookings on Traveloka \\
\hline & I feel that online booking at Traveloka is more efficient (bookings can be made throughout the day) \\
\hline & $\begin{array}{l}\text { I feel that the online booking process at Traveloka is simpler. Fewer requirements compared to traditional } \\
\text { channels }\end{array}$ \\
\hline & I find it economical to make online bookings at Traveloka \\
\hline \multirow{3}{*}{ Subjective Norms } & My family advised me to make an online booking at Traveloka \\
\hline & A friend advised me to make an online booking at Traveloka \\
\hline & The reviews in the travel community influenced my decision to make online bookings at Traveloka \\
\hline \multirow{4}{*}{ Perceived Behavioral Control } & I feel able to make online bookings at Traveloka \\
\hline & I find the Traveloka application easy to use for online booking \\
\hline & I feel that making online bookings on Traveloka is under my control \\
\hline & I feel that in the future it will be easier to make online bookings at Traveloka \\
\hline \multirow{3}{*}{ Intention } & For traveling needs, I will make an online booking at Traveloka \\
\hline & I have a strong desire to make online bookings at Traveloka \\
\hline & I am thinking about making online bookings on Traveloka again in the future \\
\hline \multirow{3}{*}{ Online Booking Behavior } & I made online bookings on Traveloka repeatedly \\
\hline & I always increase the frequency of online booking transactions at Traveloka \\
\hline & I always increase the value of online booking transactions at Traveloka \\
\hline
\end{tabular}




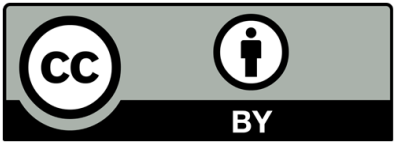

(C) 2021 by the authors; licensee Growing Science, Canada. This is an open access article distributed under the terms and conditions of the Creative Commons Attribution (CC-BY) license (http://creativecommons.org/licenses/by/4.0/). 